\title{
Przetapianie laserowe i łukiem plazmowym odlewów precyzyjnych ze stopu Inconel 713C
}

\author{
Remelting of Inconel 713C alloy by laser and plasma arc
}

\section{Streszczenie}

Odlewy precyzyjne ze stopu Inconel 713C znalazły zastosowanie na elementy silników lotniczych pracujących w wysokich temperaturach oraz w agresywnym środowisku spalin. Praktyka przemysłowa wykazała, że w procesie odlewnia precyzyjnego, tak skomplikowanych elementów, pojawiają się wady odlewnicze w postaci rzadzizn, porowatości oraz pęknięć. Powoduje to konieczność opracowania technologii naprawy tego typu odlewów. W pracy przedstawiono wyniki badań metalograficznych napoin na nadstopie niklu Inconel 713C, wykonanych laserem oraz za pomocą napawania plazmowego. Proces napawania prowadzono na modelowych płytach próbnych, w celu określenia problemów technologicznych i materiałowych związanych ze spawalnością stopu Inconel 713C. Badania obejmowały analizę makro i mikrostruktury napoiny, materiału rodzimego i strefy wpływu ciepła. Wyniki badań strukturalnych obszarów napoin wskazują, że stop Inconel $713 \mathrm{C}$ należy zaliczyć do materiałów trudno spawalnych. W napoinach wykonanych laserowo ujawniono pęknięcia materiału głównie w strefie wpływu ciepła oraz na linii wtopienia, gdzie na nadtopionych ziarnach krystalizują kryształy napoiny. Tego typu pęknięć nie obserwowano w napoinach wykonanych plazmowo. Stwierdzono, ze względu na możliwość ręcznego napawania oraz brak niezgodności spawalniczych, technologią o większym potencjale zastosowania jest napawanie plazmowe.

Słowa kluczowe: Inconel 713C; napawanie; odlewy precyzyjne; pęknięcia gorące; nadstopy niklu

\begin{abstract}
Inconel 713Cprecision castings are used as aircraft engine components exposed to high temperatures and the aggressive exhaust gas environment. Industrial experience has shown that precision-cast components of such complexity contain casting defects like microshrinkage, porosity, and cracks. This necessitates the development of repair technologies for castings of this type. This paper presents the results of metallographic examinations of pad welds on the Inconel 713C nickel-based superalloy, made by laser and by plasma-arc pad welding. The pad welding process was carried out on model test panels in order to determine the technological and material-related problems connected with the weldability of the Inconel $713 \mathrm{C}$ alloy. The studies included analyses of the macro- and microstructure of the pad welds, the base materials, and the heat-affected zones. The results of the structural analyses of the pad welds indicate that Inconel $713 \mathrm{C}$ should be classified as a low-weldability material. In the pad welds made by laser, cracks were identified mainly in the heat-affected zone and at the melted zone interface, where pad weld crystals formed on partially-melted grains. Cracks of this type were not identified in the pad welds made using the plasma-arc method. It has been concluded that due to the possibility of manual pad welding and the absence of welding imperfections, the technology having the greater potential for application is plasma-arc pad welding.
\end{abstract}

Keywords: Inconel 713C; padding welds; precision castings; hot cracking; nickel superalloy

\section{Wprowadzenie}

Nadstopy niklu, ze względu na swoje właściwości stosowane są w różnych gałęziach przemysłu m.in. w przemyśle chemicznym, energetycznym, spożywczym, lotniczym itd. Charakteryzują się wysoką odpornością na pełzanie, odpornością na korozję oraz stabilną strukturą, co składa się na stabilne właściwości mechaniczne w podwyższonej temperaturze $[1,2]$.
Odlewnicze nadstopy niklu stosowane w lotnictwie zawierają liczne pierwiastki stopowe, m.in. Ti, Al, Mo, W, Nb, Zr, $B, V, Y, L a, R e$. Jednym z takich nadstopów jest Inconel $713 \mathrm{C}$, który z powodzeniem wykorzystywany jest na odpowiedzialne elementy pracujące $\mathrm{w}$ zakresie temperatur $700 \div 950^{\circ} \mathrm{C}$, np. łopatek turbiny niskiego ciśnienia, segmenty łopatek kierujących, (rys. 1a). Inconel $713 \mathrm{C}$ należy do grupy

Dr hab. inż. Janusz Adamiec, prof. PŚl; mgr inż. Katarzyna Łyczkowska- Politechnika Śląska.

Autor korespondencyjny/Corresponding author: janusz.adamiec@polsl.pl 
a)
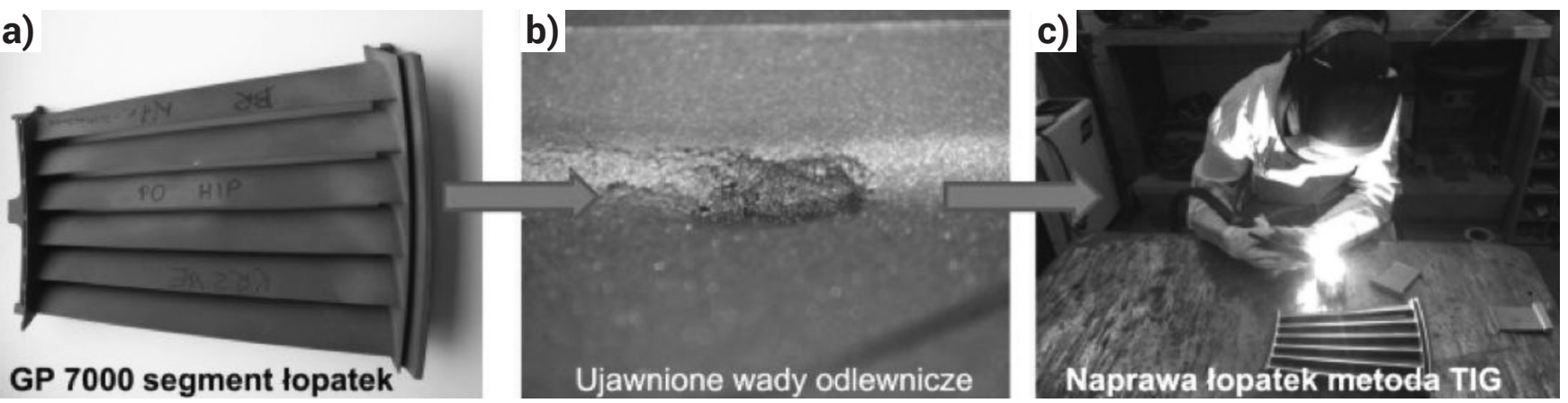

Rys. 1. Naprawa segmentu topatek ze stopu Inconel 713C: a) segment topatek kierujących, b) ujawnione wady powierzchniowe w odlewie zakwalifikowane do naprawy, c) naprawa wad za pomocą napawania metodą TIG [8]

Fig. 1. Repair of an Inconel 713C blade segment: a) a guide blade segment, b) surface defects identified in the casting and classified as requiring repair, $\mathrm{c}$ ) repairing defects by TIG pad welding [8]

polikrystalicznych nadstopów niklu umacnianych wydzieleniowo. Charakteryzuje się gęsto upakowaną ściennie centrowaną strukturą, na którą składają się koherentne wydzielenia fazy $\gamma^{\prime}$ (Ni3Al) stanowiące min. 50\% struktury, dendryty niklowe, a także eutektyczne i pierwotne węgliki MC. Umożliwia to osiągnięcie stabilnego wiązania $\mathrm{Y} / \mathrm{Y}^{\prime}$ hamującego ruch dyslokacji. Ten mechanizm umocnienia wpływa na wzrost odporności na pełzanie w podwyższonej temperaturze [3,4]. Właściwości mechaniczne stopu zależą głównie od kształtu, rozmiaru i udziału objętościowego cząstek fazy y', które mogą się zmieniać w zależności od parametrów pracy oraz zastosowanej obróbki cieplnej [5].

Podstawową technologią wytwarzania elementów ze stopu Inconel $713 \mathrm{C}$ jest odlewanie precyzyjne [6]. Jest to technologia skomplikowana i kosztowna, ale w efekcie otrzymuje się gotowy kształt, który po obróbce wykańczającej i obróbce cieplnej może być stosowany w silnikach lotniczych [6]. W procesie tym pojawiają się jednak wady. Są to głównie pęknięcia, rzadzizny oraz pęcherze (rys. 1b) [7]. Wady te dyskwalifikują odlew do dalszej eksploatacji. Obecnie podejmowane są próby naprawy tych wad za pomocą technologii spawalniczych (rys. 1c).

Analiza literatury wykazuje, że stop Inconel 713C uznawany jest za materiał trudno spawalny. Główną przyczyną jest jego złożona struktura odlewnicza, duża ilość węglików oraz często skomplikowane cienkościenne odlewy.

Podjęte próby przetapiania i napawania metodą TIG nie dały pozytywnych rezultatów. W strukturze napoin obserwowano pęknięcia w strefie wpływu ciepła oraz na linii stopienia. Pęknięcia te zlokalizowane były na granicach krysz- tałów, a opisany w pracy [8] mechanizm ich powstawania był związany z nadtapianiem się niskotopliwych faz węglikowych.

Rozwój nowoczesnych technologii napawania m.in. technologii plazmowych oraz napawania laserowego umożliwia wykorzystanie tych metod do naprawy wad w odlewach precyzyjnych. W pracy przedstawiono wyniki badań strukturalnych przetopień i napoin na próbkach odlewanych precyzyjnie ze stopu Inconel $713 \mathrm{C}$ wykonanych laserem i za pomocą łuku plazmowego.

\section{Metodyka i wyniki badań}

Celem badania była ocena struktury w obszarze przetopienia, strefy wpływu ciepła (SWC) oraz materiału rodzimego (MR) napoin odlewów precyzyjnych ze stopu Inconel 713C. Do napawania wykorzystano odlewy precyzyjne w postaci płytek o grubości 1, 3, i $5 \mathrm{~mm}$. Odlewy zostały wykonane w Pratt \& Whitney Rzeszów S. A. w ramach projektu finansowanego przez NCBiR [9]. Skład chemiczny materiału do badań potwierdzono za pomocą analizy XRF wykonanej urządzeniem Niton HLt 898W (tabl. 1, rys. 2a). Na podstawie analizy wyników zawartości pierwiastków oraz widma promieniowania RTG stwierdzono, że badany stop spełnia wymagania specyfikacji materiału. Badania metalograficzne wykazały, że stop w stanie wyjściowym charakteryzuje się strukturą dendrytyczną zbudowaną z kryształów fazy y o strukturze RSC (A1), w której są rozpuszczone pierwiastki stopowe $\mathrm{Cr}$, Co, Mo oraz w obszarach międzydendrytycznych z eutektyki $\mathrm{Y} / \mathrm{Y}^{\prime}$ (Ni3(AI,Ti)) i pojedynczych wydzieleń węglików (rys. 2b). a)

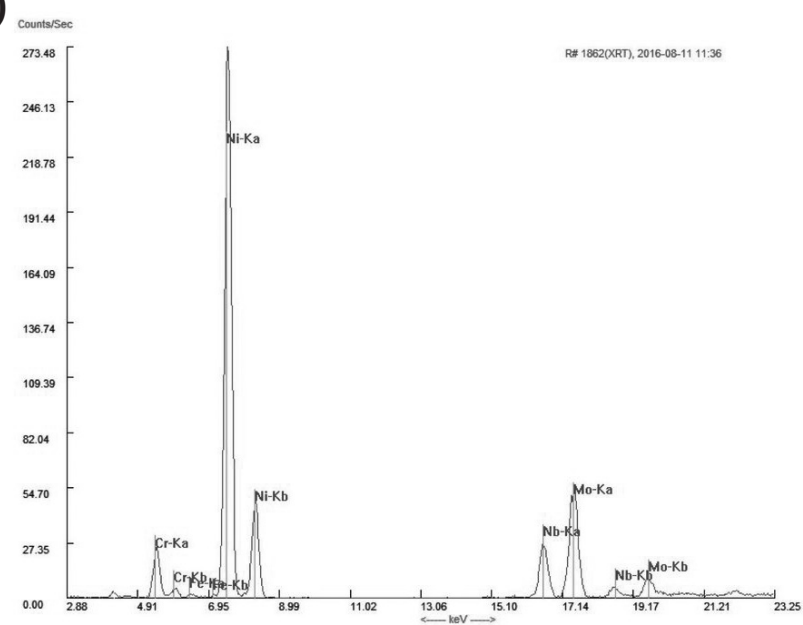

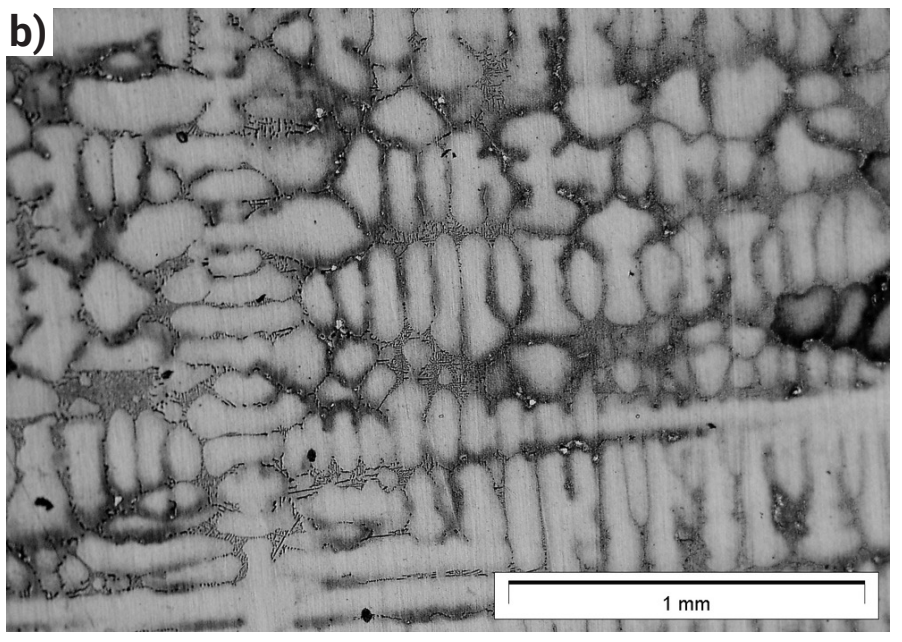

Rys. 2. a) widmo XRF przedstawiające skład chemiczny stopu IN713C, b) mikrostruktura stopu w stanie po odlewaniu

Fig. 2. a) XRF spectrum showing the chemical composition of the IN713C alloy, b) microstructure of the alloy in the as-cast condition 
Tablica I. Skład chemiczny stopu IN 713C wyznaczony metodą XRF Table I. Chemical composition on IN 713C (XRF method)

\begin{tabular}{|c|c|c|c|c|c|c|c|c|c|c|c|c|}
\hline $\begin{array}{c}\text { Skład } \\
\text { chemiczny }\end{array}$ & $\mathbf{N i}$ & $\mathbf{C r}$ & $\mathbf{A l}$ & $\mathbf{M o}$ & $\mathbf{N b}$ & $\mathbf{Z r}$ & $\mathbf{W}$ & $\mathbf{C u}$ & $\mathbf{C o}+\mathrm{Ta}$ & $\mathbf{F e}$ & $\mathbf{M n}$ & $\mathrm{Ti}$ \\
\hline IN 713C (XRF) & 70,38 & 13,29 & 5,78 & 4,44 & 2,13 & 0,04 & 0,31 & 0,47 & 1,92 & 0,36 & 0,08 & 0,8 \\
\hline $\begin{array}{c}\text { IN 713C } \\
\text { wg AMS 5391 }\end{array}$ & reszta & $12-14$ & $5,5-6,5$ & $3,8-5,2$ & $<2,5$ & $<0,15$ & - & $<0,5$ & $1,8-2,8$ & $<2,5$ & $<0,25$ & $0,5-1,0$ \\
\hline
\end{tabular}

Próby technologiczne napawania plazmowego i laserowego prowadzono w Instytucie Spawalnictwa w Gliwicach. Przetopienia i napawanie łukiem plazmowym wykonano w osłonie gazu obojętnego (argon) o przepływie $6 \mathrm{l} / \mathrm{min}$, elektrodą wolframową o średnicy $1,6 \mathrm{~mm}$, przy zastosowaniu dyszy plazmowej o średnicy 1,2 mm. Przetopienia wykonano w pozycji podolnej, prądem stałym o natężeniu $5 \div 18 \mathrm{~A}$ i napięciu łuku $16 \div 20 \mathrm{~V}$. Do napawania stosowano materiał dodatkowy odpowiadający specyfikacji dla stopu Inconel 625.
Przykładowe lica przetopień pokazano na rysunku 3a.

Do przetapiania laserowego wykorzystano laser dyskowy Trumph LaserDysk 12002 o mocy 12 kW z głowicą D70 Hybrid i światłowodem o średnicy 0,3 mm. Ogniskowa wiązki wynosiła: $400 \mathrm{~mm}$, a średnica ogniska: 0,6 mm. Płytki próbne przetapiano stosując moc wiązki w zakresie od $1 \mathrm{~kW}$ do 2,5 kW, prędkość przetapiania wynosiła $1 \div 2 \mathrm{~m} / \mathrm{min}$. Proces prowadzono w osłonie argonu. Lica wykonanych przetopień pokazano na rysunku 3b. a)

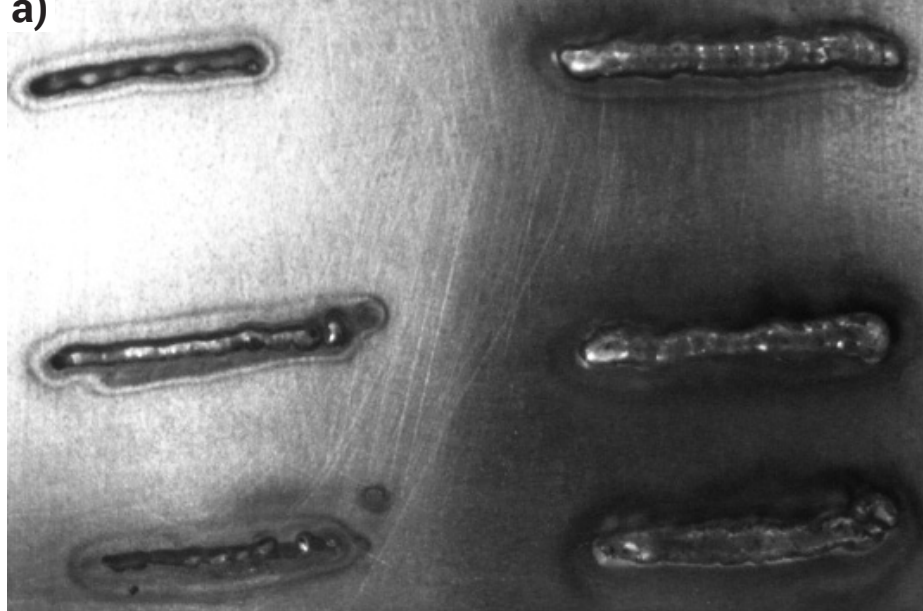

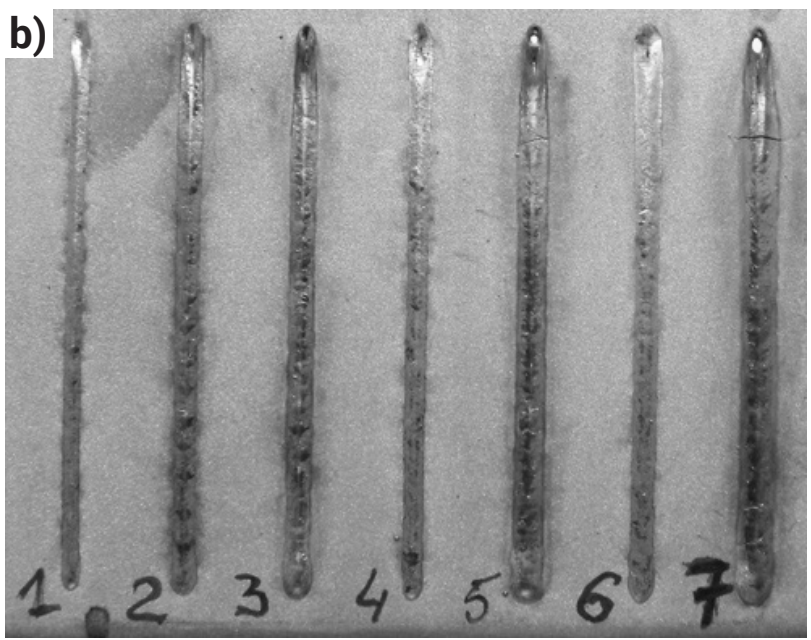

Rys. 3. Przetopienia i napoiny próbne na płytkach odlewanych ze stopu Inconel 713C: a) napoiny wykonane łukiem plazmowym, b) przetopienia wykonane laserowo

Fig. 3. Experimental melting and pad welding on Inconel $713 \mathrm{C}$ plates: a) pad welds made using a plasma arc, b) pad welds made by laser
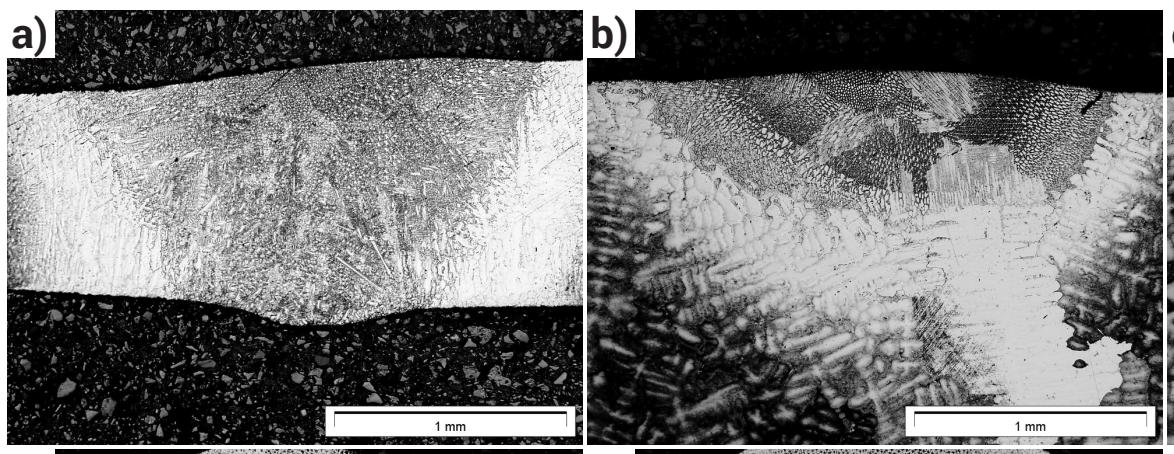

c)
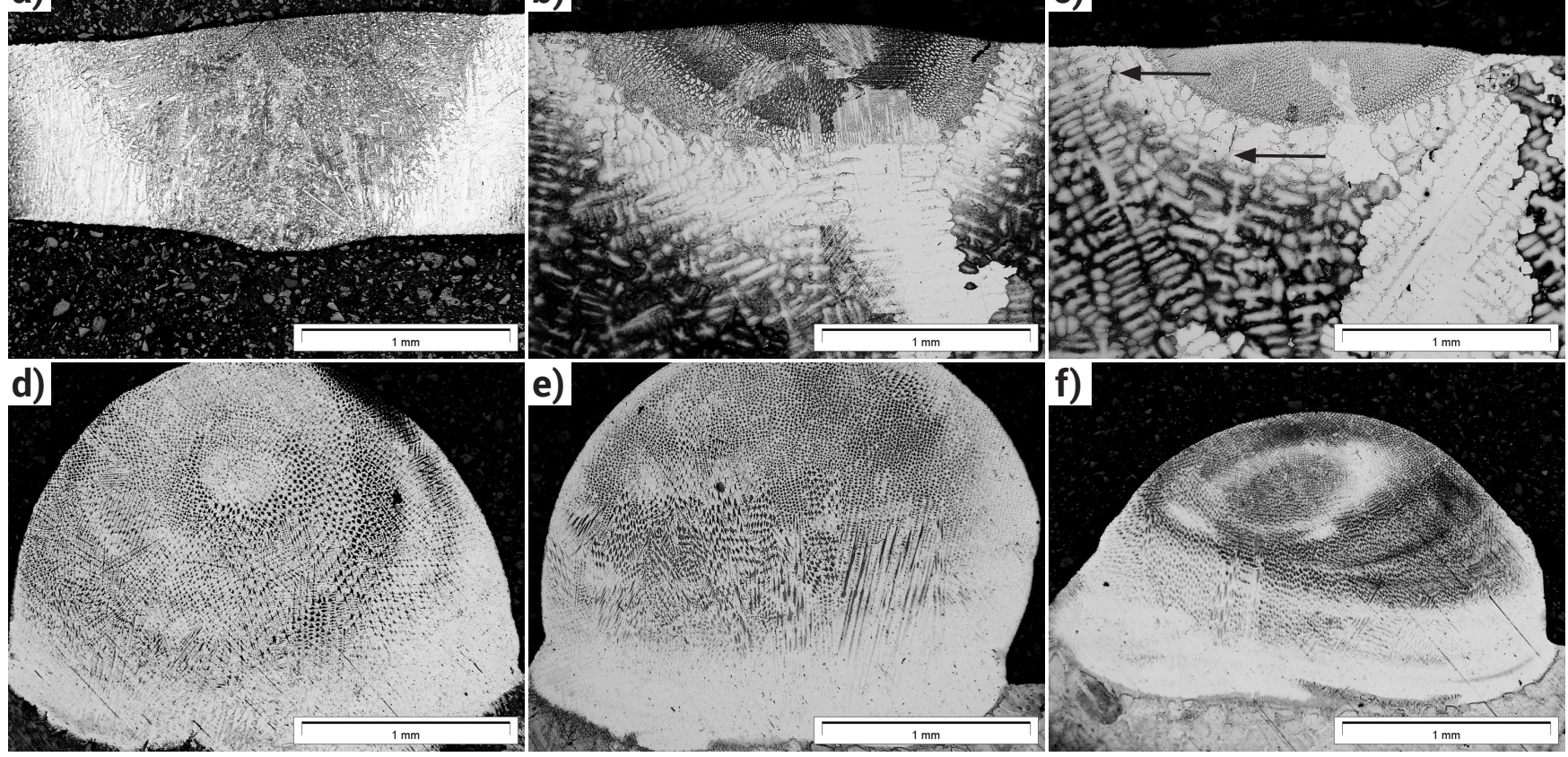

f)

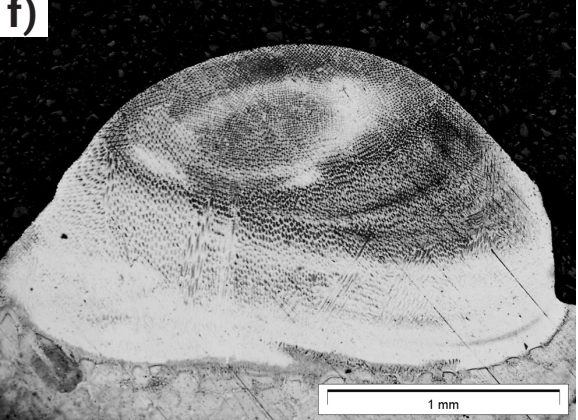

Rys. 4. Makrostruktura przetopień i napoin wykonanych plazmą: a) przetopienie płytki o grubości $1 \mathrm{~mm}$, b) przetopienie płytki 3 mm, c) przetopienie płytki o grubości $5 \mathrm{~mm}$, d) napoina na płytce o grubości $1 \mathrm{~mm}$, e) $3 \mathrm{~mm}$, f) $5 \mathrm{~mm}$ (strzałkami zaznaczono ujawnione pęknięcia) Fig. 4. Macrostructure of the melted areas and pad welds made by plasma arc: a) melted area on the $1 \mathrm{~mm}$ thick plate, b) melted area on the $3 \mathrm{~mm}$ thick plate, c) melted area on the $5 \mathrm{~mm}$ thick plate, d) pad weld on the $1 \mathrm{~mm}$ thick plate, e) $3 \mathrm{~mm}$, f) $5 \mathrm{~mm}$ (the cracks identified are indicated with arrows) 
Próbki do badań metalograficznych zostały wycięte prostopadle do kierunku przetapiania tak, aby ujawnić wszystkie jego strefy. Następnie próbki szlifowane były na papierach ściernych i polerowane za pomocą past diamentowych. Do ujawnienia struktury materiał trawiono $\mathrm{w}$ odczynniku o składzie chemicznym: $\mathrm{FeCl}_{3}, \mathrm{CuCl}_{2} \cdot 2 \mathrm{NH}_{4} \mathrm{Cl} \cdot 2 \mathrm{H}_{2} \mathrm{O}, \mathrm{HNO}_{3}, \mathrm{HCl}$ i $\mathrm{H}_{2} \mathrm{O}$. Badania metalograficzne prowadzono na mikroskopie stereoskopowym SZX9 (SM) przy powiększeniach do 50x (rys. 4, 5), mikroskopie świetlnym Olympus GX71 (LM) przy powiększeniach do 500x w technice pola jasnego (rys. 6, 7).
Wykonano również badania struktury na elektronowym mikroskopie skaningowym JEOL JCM-6000 Neoscope II (SEM). Rejestracji obrazów dokonano w technice elektronów wtórnych SE, przy powiększeniu do 1000x i napięciu przyspieszającym wiązkę elektronów $15 \mathrm{keV}$. Uzupełnieniem badań była mikroanaliza składu chemicznego wykonana metodą EDS w strefie ujawnionych pęknięć. Przykładowe wyniki tych badań pokazano odpowiednio na rysunku 8 dla przetapiania łukiem plazmowym i rysunku 9 dla przetapiania wiązką lasera.
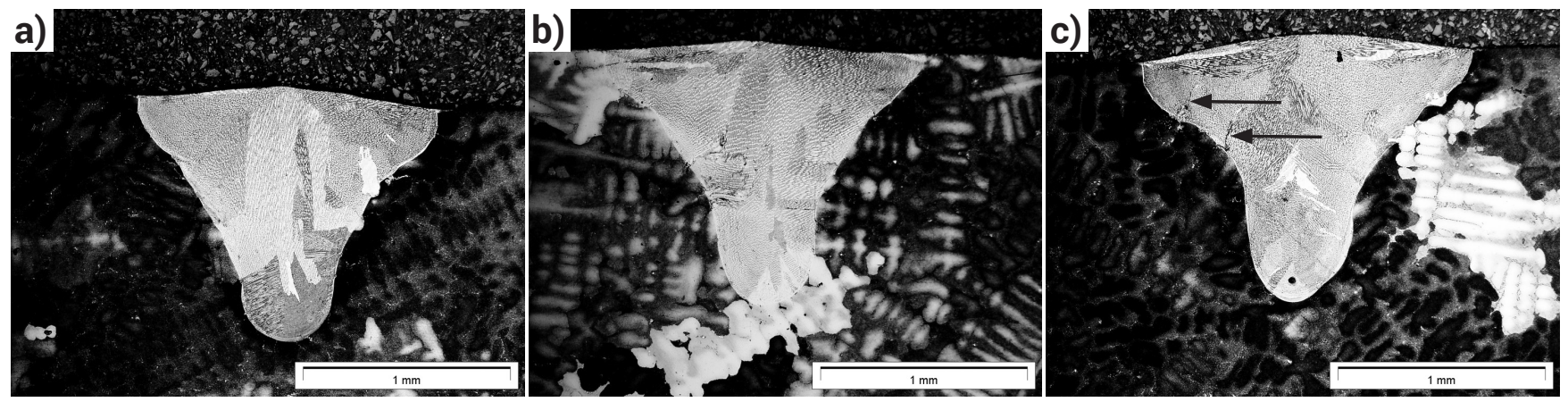

Rys. 5. Makrostruktura przetopień wykonanych laserem dyskowym: a) płytka o grubości $1 \mathrm{~mm}$, b) płytka o grubości 3 mm, c) płytka o grubości $5 \mathrm{~mm}$ (strzałkami zaznaczono ujawnione pęknięcia)

Fig. 5. Macrostructure of the melted areas and pad welds made by disk laser. a) $1 \mathrm{~mm}$ thick plate, b) $3 \mathrm{~mm}$ thick plate, c) $5 \mathrm{~mm}$ thick plate (the cracks identified are indicated with arrows)
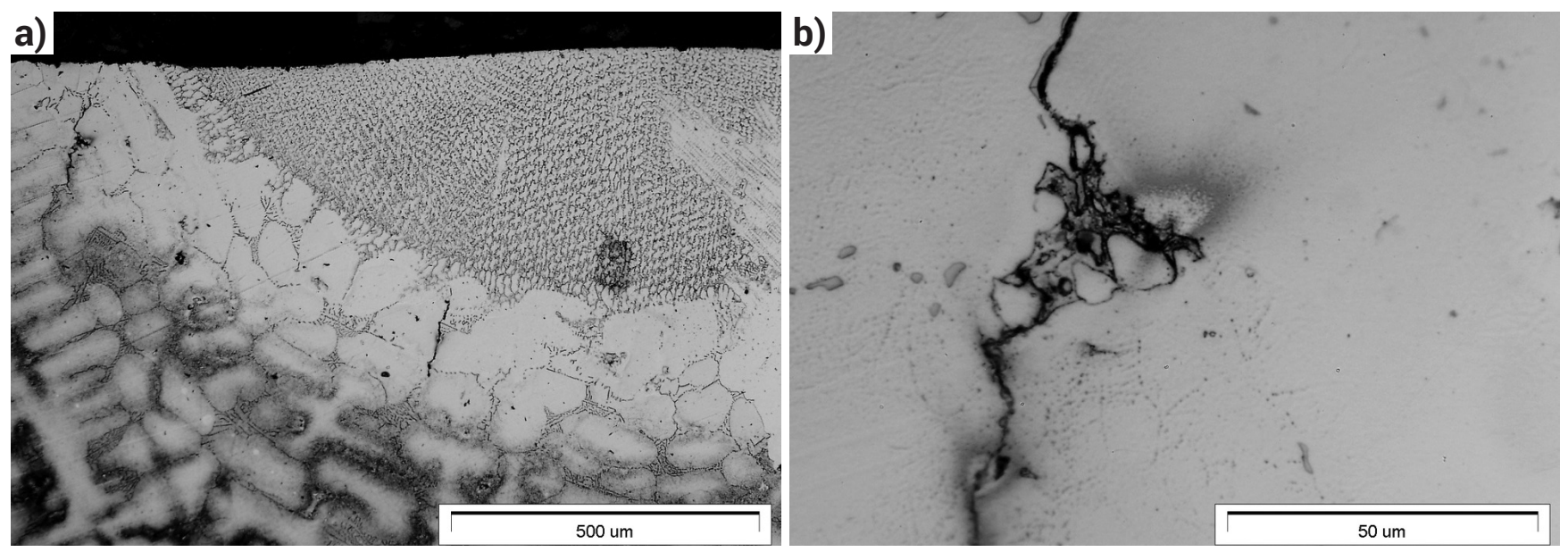

Rys. 6. Ujawnione pęknięcia w strukturze przetopień odlewu ze stopu Inconel 713C (łuk plazmowy): a) pęknięcia po granicach kryształów w SWC, b) pęknięcie w SWC związane z nadtapianiem eutektyki i węglików

Fig. 6. Cracks identified in the structure of the melted zone on an Inconel $713 \mathrm{C}$ casting (plasma arc): a) cracks along crystal boundaries in the HAZ, b) a crack in the HAZ related to the partial melting of the eutectic mixture and carbides
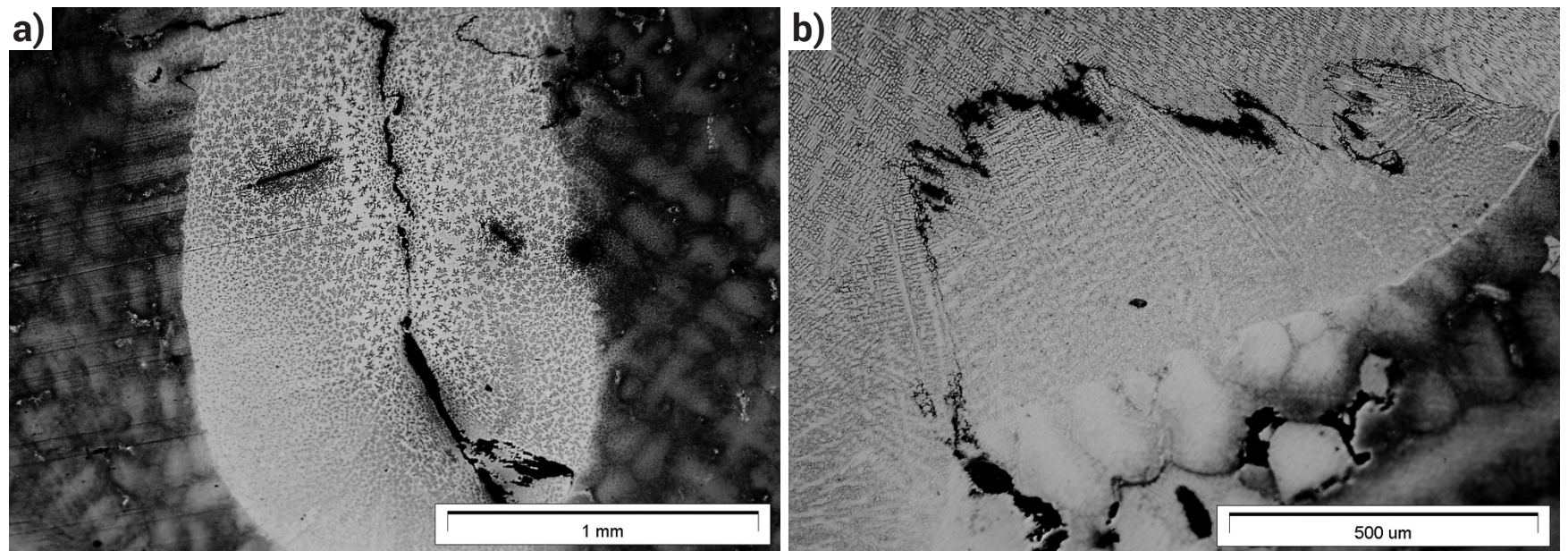

Rys. 7. Pęknięcia w strukturze przetopień laserowych odlewu ze stopu Inconel 713C: a) pęknięcia gorące w spoinie, b) pęknięcie na linii wtopienia po granicy kryształów

Fig. 7. Cracks in the structure of the laser melted area on an Inconel $713 \mathrm{C}$ casting: a) hot cracks in the melted zone, b) crack along crystal boundaries at the fusion line 

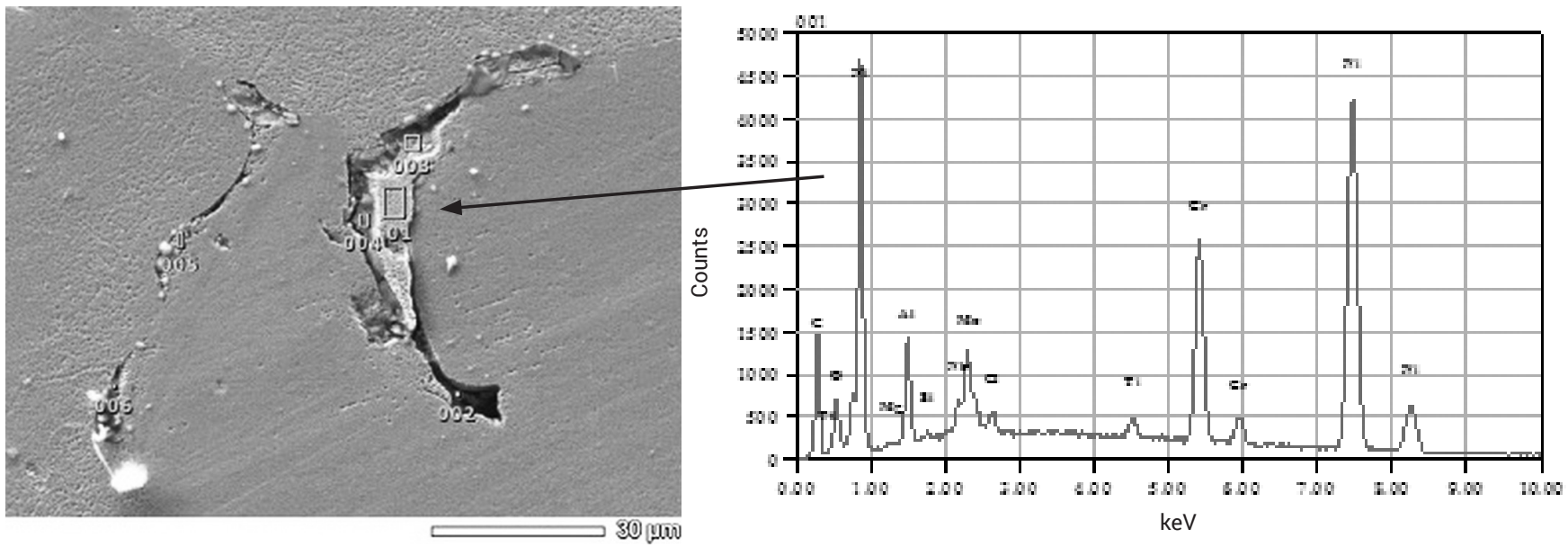

Rys. 8. Wyniki mikroanalizy składu chemicznego w obszarze pęknięcia w SWC próbki przetapianej łukiem plazmowym

Fig. 8. Results of the chemical composition microanalysis of the crack area in the HAZ - specimen melted by plasma arc
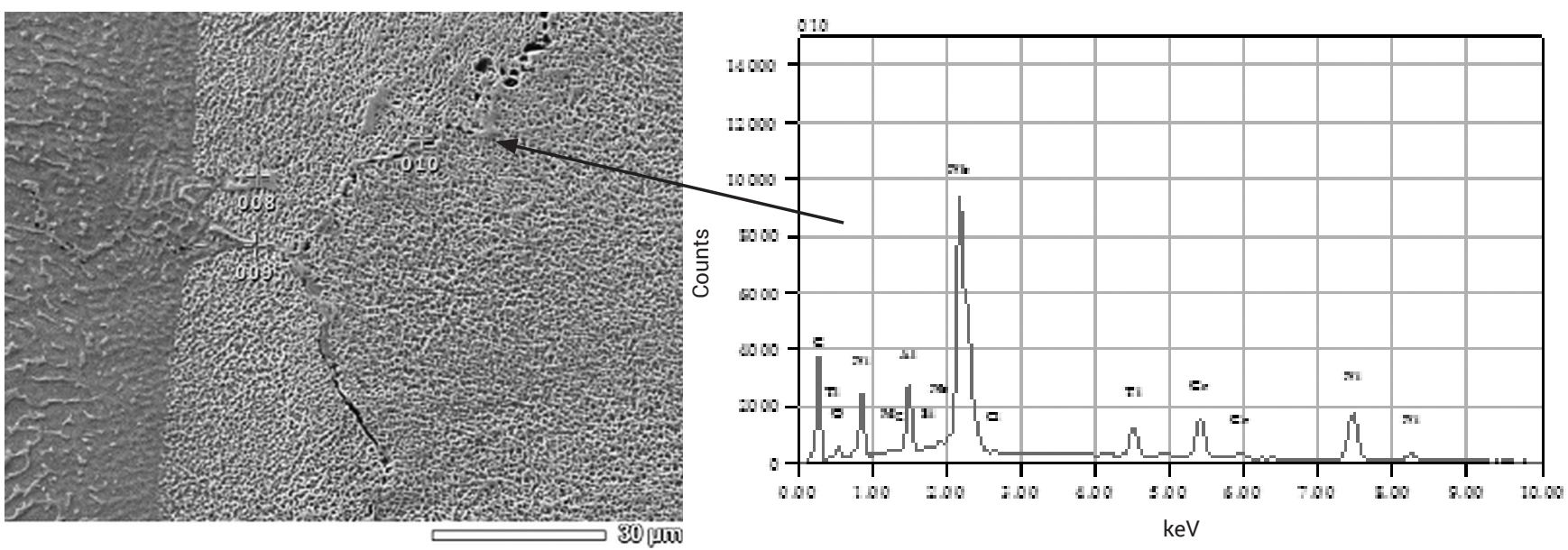

Rys. 9. Wyniki mikroanalizy składu chemicznego na linii wtopienia próbki przetapianej laserem

Fig. 9. Results of the chemical composition microanalysis at the fusion line - specimen melted by laser

\section{Podsumowanie}

Przeprowadzono próby przetapiania i napawania płyt próbnych ze stopu Inconel 713C odlewanych precyzyjnie. Przetapianie wykonano łukiem plazmowym o natężeniu prądu do $18 \mathrm{~A}$ w osłonie gazu obojętnego oraz laserem dyskowym, wiązką laserową o mocy do 2,5 kW. Próby miały na celu wstępne określenie spawalności odlewów precyzyjnych ze stopu Inconel 713C, charakteryzujących się zróżnicowaną grubością ścianek oraz sformułowanie wstępnych wytycznych do opracowania technologii naprawy tego typu odlewów.

Ocena makrostruktury przetopień wykonanych łukiem plazmowym nie ujawniła pęknięć w płytach o grubości $1 \mathrm{~mm}$ i $3 \mathrm{~mm}$ (rys. 4a, 4b), natomiast w przypadku przetapiania płyty o grubości $5 \mathrm{~mm}$ stwierdzono pęknięcia w strefie wpływu ciepła (rys. 4c). Szczegółowe badania metalograficzne wskazują, że są to pęknięcia powstające w wyniku nadtopienia się obszarów międzydendrytycznych w materiale rodzimym (rys. 6a), a następnie ze względu na odkształcenia podczas krystalizacji jeziorka ciekłego metalu następuje rozerwanie warstewki cieczy międzydendrytycznej (rys. 6b). Potwierdzają to wyniki badań na elektronowym mikroskopie skaningowym i wyniki mikroanalizy składu chemicznego EDS w obszarze pęknięcia (rys. 8). Stwierdzono, że skład chemiczny faz ujawnionych na powierzchni pęknięcia jest zbliżony do składu materiału rodzimego, co wskazuje na nadtopienie się kryształów, a następnie warstewka cieczy krystalizuje na ich powierzchni. Ten rodzaj pękania jest związany z opisanym w literaturze nadtapianiem się materiału w strefie częściowego stopienia [9].

Znacznie lepsze wyniki uzyskano przy napawaniu płyt próbnych z materiałem dodatkowym. Badania metalograficzne nie ujawniły mikropęknięć, jedynie kształt napoiny jest niekorzystny, tzn. kąt przejścia pomiędzy licem napoiny a materiałem rodzimym jest duży (ok. 90) (rys. 4d, 4f). Jednak ze względu na fakt, że w technologii naprawy odlewów precyzyjnych przewiduje się obróbkę ubytkową, niezgodność ta jest akceptowalna.

Analiza przetopień wykonanych wiązką laserową wykazała, że kształt przetopienia jest prawidłowy i zależy od mocy wiązki oraz miejsca pozycjonowania ogniska wiązki (rys. 5). We wszystkich analizowanych przypadkach stwierdzono pęknięcia gorące w spoinie (rys. 7), co związane jest z szybkim procesem krystalizacji oraz wynikającymi z tego naprężeniami, odkształceniami i skurczem materiału. 
Analiza obszaru pęknięcia wskazuje, że jednym z mechanizmów pękania jest mechanizm opisany w pracy [9]. W wyniku działania ciepła wiązki laserowej następuje nadtapianie się węglików (np. NbC) po granicach ziaren, a następnie podczas krystalizacji powstaje eutektyka (rys. 9). Związany z tym zjawiskiem skurcz powoduje powstanie pęknięcia.

Na podstawie przeprowadzonych badań stwierdzono, że napawanie plazmowe z materiałem dodatkowym umożliwia przeprowadzenie naprawy odlewów precyzyjnych ze stopu Inconel 713C bez pęknięć gorących.

Praca sfinansowana w ramach Programu Badań Stosowanych finansowanego przez Narodowe Centrum Badań i Rozwoju, projekt pt.: "Zaawansowane technologie odlewnicze" - INNOCAST", nr umowy INNOLOT/I/8/NCBR/2013.

\section{Literatura}

[1] http://www.bibusmetals.pl/fileadmin/editors/countries/bmpl/Data_sheets/Inconel_600_karta_katalogowa.pdf (08.07.2016)

[2] S. Kocańda: Poradnik Inżyniera Mechanika. Tom 1, WNT, Warszawa 1968.

[3] F. Mastromateo, F. Mammoliti, M. Giannozzi, M. Romanelli, D. Ficorilli: Metal temperature map determination of a serviced gas turbine bucket and comparision with FEM temperature distribution. Proceedings of ASME Turbo Expo 2006 Power of Land, Sea and Air; May 8-11, 2006, Spain, Barcelona (2006).

[4] F. Zupaniĉ, T. Bonĉina, A. Kiržman, F. D. Tichelaar: Structure of continuously cast Ni-based superalloy Inconel 713C. Journal of Alloys and Compounds 329 (2001) pp. 290-297.
[5] A. Ges, H. Palacio, R. Versaci: Inconel 713C Characteristic properties optimized through different heat treatments. Journal of Material Science, Vol. 29 (1994) pp. 3572-3576.

[6] https://www.nickelinstitute.org/ /media/Files/TechnicalLiterature/Alloy713C_337_.ashx (08.07.2016)

[7] A. Szczotok, B. Kościelniak:Characterization of IN713C superalloy microstructure after high temperature creep test by LM, SEM and STEM, Inżynieria Materiałowa, Vol. 2 (2016) pp. 50-58.

[8] K. Łyczkowska: Struktura przetopień odlewów precyzyjnych ze stopu Inconel 713C, XLIV Szkoła Inżynierii Materiałowej, Kraków - Rytro 2016.

[9] E. Tasak, Metalurgia spawania, Wydawnictwo JAK, Kraków 2008. 